\title{
Local wisdom Pasang ri Kajang as a political power in maintaining indigenous people's rights
}

\author{
Gustiana Anwar Kambo \\ Department of Political Science, Faculty of Social and Political Sciences, Hasanuddin University, \\ Indonesia.
}

Correspondance author: gustianakambo@yahoo.com

\begin{tabular}{|c|c|}
\hline ARTICLE INFO & ABSTRACT \\
\hline $\begin{array}{l}\text { Keywords: } \\
\text { Local wisdom; Indigenous } \\
\text { people; Kajang; Political } \\
\text { power; Conflict. } \\
\text { How to cite: } \\
\text { Kambo, G.A. (2021). Local } \\
\text { wisdom Pasang ri Kajang } \\
\text { as a political power in } \\
\text { maintaining indigenous } \\
\text { people's rights. } \\
\text { ETNOSIA: Jurnal } \\
\text { Etnografi Indonesia. 6(2), } \\
\text { 265 - 280. } \\
\\
\text { DOI: } \\
\text { 10.31947/etnosia.v6i2.10585 }\end{array}$ & $\begin{array}{l}\text { This research analyzes Pasang ri Kajang as local wisdom in } \\
\text { Indigenous people Ammatoa Kajang becomes a social and political } \\
\text { power. It maintains the existence of indigenous people Ammatoa } \\
\text { Kajang in the customary land conflict with PT London Sumatra } \\
\text { (Lonsum). Indigenous Peoples of Ammatoa Kajang, known as } \\
\text { indigenous people who uphold the values of local wisdom, was called } \\
\text { Pasang ri Kajang; one of them is their belief that forests are the center } \\
\text { of life. The conflicthas arisen since PT Lonsum has unilaterally taken } \\
\text { over Ammatoa Kajang's customary land in several villages. The lack } \\
\text { of regulation of the local government that protects the rights of the } \\
\text { Kajang community makes the position of the Ammatoa Kajang } \\
\text { indigenous community weak in resisting. The indigenous Ammatoa } \\
\text { Kajang community and several environmental and indigenous } \\
\text { peoples' institutions demanded that the Bulukumba district } \\
\text { government make and ratify the Ranperda of the Ammatoa Kajang } \\
\text { community that could protect the rights and recognition of the } \\
\text { Ammatoa Kajang customary community. At the end of 2015, the } \\
\text { Bulukumba district government ratified regional regulation No. } \\
\text { 9/2015 about the Inauguration, Recognition, and Protection of } \\
\text { Customary Law Communities Ammatoa Kajang. Ratification of this } \\
\text { regulation is a form of deregulation carried out by the Bulukumba } \\
\text { district government in responding to conflicts over land and forest } \\
\text { struggles of the indigenous people of Ammatoa Kajang and PT. } \\
\text { Lonsum. }\end{array}$ \\
\hline
\end{tabular}

\section{Introduction}

The indigenous people of Ammatoa Kajang are one of the indigenous peoples whose existence still persists until now. As one of the people who adheres to customary values that have been passed down from generation to generation, making them have cultural values that cannot be violated either by members of the indigenous community or by communities outside the indigenous community. However, the values possessed by 
indigenous people in fact are often violated and even become conflicts between indigenous peoples and outside communities.

In 1979 there was a conflict over forest and customary land between the Kajang customary community and PT. London Sumatra (Lonsum). PT. Lonsum displaced around 300 houses on the grounds of adding 373 hectares of plantation area in Balong village, Ujun sub-district, Loe. After the incident, a meeting was held between PT. Lonsum with the local community facilitated by the Bulukumba district government. The meeting resulted in an agreement. First, PT . Lonsum will not expand his plantation area until there is a decision from the Bulukumba district court. Second, the company the government will compensate for the evictions carried out by PT. Lonsum. Third, families from the local community will be made employees of the company. But in 1980 before the decision was issued from the district court of Bulukumba district, PT. Lonsum violated the agreement and again expanded the area of rubber plantations on ulayat Kajang land covering an area of 1000 hectares.

In 1981-1988 there was an expansion of plantation area carried out by PT. Lonsum in the villages of Bonto Biraeng, Desa Jo'jolo and the village of Tugondeng which affected evictions of approximately 500 residents and land grabbing of ulayat Kajang covering an area of 540.6 hectares and 373 hectares. The expansion of the area that continues to be carried out by PT. Lonsum indicated two important things, first, the weak role of the district government in controlling the activities of foreign companies in Bulukumba district. Secondly, the rights and authority of the Kajang customary community to be of no value or even ignored, indigenous peoples do not have power over their own customary territories. Based on the two things that the writer indicated earlier, the country's perspective is the main highlight in this study. The role of the state as an organization that is ideally able to provide welfare and security for all its people has not been able to carry out its functions to the fullest. In several meetings which resulted in an agreement between the Kajang customary community, the local government and PT Lonsum included replacing community losses due to the conflict over forest and customary land, in fact it was only temporary so that conflicts over the customary land could be resolved at any time.

The main role of the regional government for the Kajang customary community is regulation in legal protection to maintain its existence. In the Decree of the Constitutional Court No. 35 of 2012 states that forests within the territory of indigenous peoples belong to indigenous peoples, but this regulation is not strong enough as a foundation for protecting the rights of indigenous peoples, especially those concerning customary land. There is no law in the constitution specifically to discuss the recognition and rights of indigenous peoples, even though the acknowledgment has been stated in Article 18 B of the Constitution (2) which reads:

"The State recognises and respects traditional communities along with their traditional customary rights as long as these remain in existence and are in accordance with the societal development and the principles of the Unitary State of the Republic of Indonesia, and shall be regulated by law". (Constitution of the Republic of Indonesia) 
In reality the rights of indigenous peoples and even things that are sacred cultural values become unprotected from irresponsible parties. The Kajang customary community still needs regulations that are able to protect their rights as elements of Indonesian society. In 2013 the Kajang indigenous people together with the Indigenous Peoples Alliance of the Archipelago (AMAN) submitted a regional regulation that was able to protect the rights of the Kajang indigenous people. This is greatly appreciated by the DPRD of Bulukumba Regency, but in the process of making there are many obstacles, even as of 2015 the Ranperda, which is scheduled to be completed by the end of 2014, is still unresolved. Based on these background, this research aims to identification the efforts of the Ammatoa Kajang Indigenous People to fight for their rights to the management of their communal land and forest. Based on it, the study used Pasang ri Kajang as Indigenous knowledge and regulation theory by Robert Boyer as theoriticals frame.

Pasang ri Kajang are messages in the form of advice and trust from the ancestors that are very sacred and can have a negative impact if violated. In Pasang ri Kajang, there is a belief that is Pa'tuntung (Hijjang, 2005) . In Patuntung's belief there are values relating to the maintenance and preservation of forest ecosystems. The indigenous people of Ammatoa Kajang as followers of the Patuntung Trust maintain the sustainability of their forest ecosystem. They believe that forest ecosystems cannot be separated from the structure of their beliefs. In other words, Patuntung's trust holds a key regulation (regulator key) between the population of the Ammatoa Kajang customary community and its environmental components. The indigenous people of Ammatoa Kajang believe that their ancestors, known asTau Manurung (humans who descended from the sky) first set foot in the Ammatoa Kajang Forest area. So that the sacredness of the forest then penetrates into their social systems, including patterns of action and treatment of the community towards their environment. Patuntung believes that forests have two functions, namely; ritual functions and ecological functions. In the ritual function, the Ammatoa Kajang customary community believes that forests are sacred so that traditional ceremonies and other traditional activities are often carried out in the forest. While the ecological function is the forest as a regulator of water management (Appari'e bosi, appari'e tumbus) which causes rain and springs to rise. In the belief of the indigenous people of Ammatoa Kajang, it is seen that forest ecosystems have functions that are in line with the functions of forest ecosystems that are now becoming known. Apart from the ritual functions described above. This is also confirmed in a Install as follows "Punna nitabbangngi kayua, nipappirangngangngi angngurangi bosi, appatanre 'tumbusu, napau turiolowa". -If wood in the forest is cut down, it will reduce rain, eliminate springs, according to the message of the ancestors.

This tide illustrates that in Patuntung's belief looking at the function of forest ecosystems with a modern view, the forest is a source of rain and a source of water. In simple terms it can be said that the Ammatoa Kajang Customary Community views Forest as the Lung of the world.The connection of the Ammatoa Kajang Indigenous community with natural resources does not only cover the forest ecosystem, but also the elements of living things and other non-living things, such as animals, plants, sun, rain water, wood, 
forests, even bees and their nests have important functions in the network and ecological system for the Ammatoa Kajang indigenous people.

Indigenous Peoples of Ammatoa Kajang have distinctive local habits to maintain ecological balance and forest sustainability. Consequently, the Ammatoa Kajang customary community made efforts to save energy and resources by voluntarily taking the Kamase-masea lifestyle or in Kajang language to mean enough. That is, the pattern of life that is applied to the Ammatoa Kajang Indigenous people is a simple lifestyle, not lacking but not too excessive. This effort is absolutely to be carried out by the community because it deals with one of the pairs which states that maintain it while it is still there, before the crisis or Paceklik period (Katutui ririe'na rigentengng tabattuna paraya).

The pairs described illustrate that the indigenous people of Ammatoa Kajang have indigenous knowledges. Which is very effective in regulating their life patterns with the nature contained in the Kajang ri ri the awareness of the Kajang indigenous people in preserving the environment is very much in line with the proliferation of socialization regarding environmental conservation and other green political movements. Based on the understanding of the values of ecocentrism contained in the concept of Pasang ri Kajang, this will then be associated with environmental philosophical perspectives that will lead to the concept of environmental ethics.

Regulatory theory or Regulation theory coined by Robert Boyer discusses relations between the state, society and markets. The core of Boyer's thesis is the role of the state in regulating regulations governing the community and the (private) market. Institutional institutions are the main foundation before making a policy, so elements in state institutions including local governments must be able to act professionally, free from KKN and have supremacy and law enforcement so that there is no tugging of interests in the political elite (agency problem). In addition, Boyer argues that the market or private sector will be more efficient if it is regulated by the State, and can have an impact on society. Boyer also emphasized that State intervention in the market needs to be emphasized. Another thing mentioned in it is that the market mechanism in carrying out its production needs to be supervised and regulated by law, regulations, mutual agreement from both the state and the community, including abuilt in stabilizer in the tax system (Boyer, 2005).

Boyer's thinking can be adopted in cases that occur between the Kajang Ammatoa indigenous people and PT. Lonsum. the local government of Bulukumba district needs to carry out a regional legislation mechanism to PT. Lonsum as a market or private party, moreover PT. Lonsum is a foreign private company. In this problem, the government needs to carry out its role in regulating the private mechanisms that exist within the territory of its government. This is needed so that in the future there will not be a condition where the State or regional government loses power in regulating private mechanisms. If left unchecked, the worst possibility is that the private sector can take over the role of the government as a protector and guardian of welfare .

On the other hand, the role of the government does not only regulate the private mechanism or the market, in order to realize prosperity in the community, the government needs to conduct deregulation, in this case deregulation of the protection of 
the Ammatoa Kajang indigenous people. Conflict between Indigenous people of Ammatoa Kajang and PT. Lonsum has shown the lack of recognition and rights possessed by the Ammatoa Kajang customary community in dealing with the private sector. The eviction of ulayat lands and customary forests is proof of the inability of the Ammatoa Kajang customary community to maintain their existence as well as the government's weakness in maintaining the welfare of their community. Boyer (2005) giving his views regarding local communities, especially to regulate market or private mechanisms, social and political involvement cannot be avoided, so that local communities with the State need to monitor and control market or private mechanisms. (Boyer, 2005). However, in order for these objectives to be achieved, the local community, in this case the Ammatoa Kajang indigenous people need to be recognized and legally protected, have special regional laws and regulations, both for the community, the environment and culture. This article focus of the research is the strength of the Kajang Indigenous community in defending the indigenous forest in the conflict over territories with PT Lonsum.

\section{Methods}

This study uses a phenomenological qualitative research method. it is used to describe and provide an explanation of the conflict over the Kajang indigenous forest and provide a comprehensive and in-depth understanding of the phenomena that are the object of the research study. This research takes about 1 year, from 2015-2016 and located in Tana Towa village, Kajang sub-district, Bulukumba district, South Sulawesi province. The data collection technique used in-depth interviews with the main informant, namely Ammatoa as the customary leader of the Ammatoa Kajang Indigenous society, AMAN (the Alliance for Indigenous Peoples of the Nusantara), and the Ammatoa Kajang customary community.

This study uses a phenomenological qualitative research method. The focus of the research is the strength of the Kajang customary community in defending the customary forest in the conflict over territories with PT Lonsum. Phenomenological qualitative methods are used to describe and provide explanations of the Kajang community customary forest conflict and provide a comprehensive and in-depth understanding of the phenomena that are the object of research studies. This research takes about 1 year, from 2015-2016 and is located in Tana Towa village, Kajang sub-district, Bulukumba district, South Sulawesi province. The data collection technique used in-depth interviews with the main informant, namely Ammatoa as the customary leader of the Ammatoa Kajang customary community, AMAN (the Alliance for Indigenous Peoples of the Archipelago), and the Ammatoa Kajang customary community.

\section{Results and discussions}

The Ammatoa Kajang customary community has the values of local wisdom contained in a Kajang ri ri. Pasang ri Kajang contains messages, mandates and advice from previous ancestors to the next generation that is very sacred and believed by the indigenous people of Ammatoa Kajang. The highest leader in the Ammatoa Kajang customary community is known as Ammatoa 'which means it is revered and respected. The selection of leaders is not based on descent but through special 
rituals. Besides Ammatoa, there is something called Galla or ministers who take care of various fields of life. There were 12 Galla, one of whom was Galla Gantara who was in charge of environmental fields, especially huta in the customary area of Ammatoa Kajang.

Forests for the indigenous people of Ammatoa Kajang are very sacred, not only as a place to settle but also a place for performing traditional rituals and sources of livelihood, even in the Kajang ri ri there areseveral pairs/messages that contain the environment and the impacts that occur if the forest is not well guarded;

1. Naparanakkang Juku. Napaloliko Ranung Kaju. Nahambangiko Allo. Nabatuiko ere bosi. Napalolo'rang ere is old. Nakajariangko tinanang - making a splash, the trees blossomed. Mahatari shines, the rain falls. Tilapia drips everything that plants will grow (grow).

2. Anjo Boronga anre nakkule nipanraki, punna nipanraki boronga, nu panraki kalennu - the forest must not be damaged, if you destroy it as well as damage yourself.

3. Yes, minjo boronga kunne pusaka, anjo borong angngontaki bosiya, aka'na kajua aka paloppo tumbusu - hutan is our inheritance, it is the forest that brings rain, wood roots enlarge the springs. (Hijjang, 2005)

The Fact is not just a message/message that contains environmental preservation, especially forests, but in indigenous communities Ammatoa Kajang has penalties for violations of illegal logging known as Ba'bala. Ta'bang Kaju or violations of unlicensed woodcutters are divided into three; $c a^{\prime} p a b a^{\prime} b a l a$ which is a light sentence, $b a^{\prime} b a l a$ tanga namely moderate punishment and po'ko ba'bala, namely severe punishment. The mild punishment is often also called nai $i$ natusi - rises above the tree. Thieves or woodcutters are considered monkeys who like to take things that are not theirs without permission so they have to stay in trees like a monkey. The medium sentence is also known as the light sentence-ostracized in a social circle. Violations that have been committed more than once or repeatedly are analogous to greedy boar and always want to take things that are not theirs without satisfaction, so that being excluded from social life is considered commensurate with the violations committed. In Konjo language (Boyer, 2005) the severe punishment was written as mpasolongi sere'na nipa lulu 'ahunna - demolished by his house (made of nipa leaves) and then expelled. If someone in the Ammatoa Kajang customary community repeatedly violates and is not deterred, then his house will be demolished/destroyed and then expelled from the territory of the Ammatoa Kajang customary community.

The research showed that the pairs and regulations applied in the life of the Ammatoa Kajang indigenous people are an embodiment of environmental ethics . Environmental ethics are values that inform our ways to act on the environment besides that Environmental ethics is needed for the continuity of the relationship between human environment and welfare and as a director and regulator of human beings' actions and activities related to the environment (Suci, 2016).

A series of pairs and regulations of the Ammatoa Kajang customary community turned out to only apply to the environment of the Ammatoa Kajang customary community 
itself. The conflict over forest and customary land of Ammatoa Kajang by PT Lonsum since 1979 has not yet been resolved. The value of local wisdom regarding the preservation of the forests contained in the Kajang Pasang ri was ignored by PT Lonsum. If analyzed, this neglect is because the Pasang ri Kajang is not a positive law that must be adhered to by all citizens but a customary law that must be adhered to by the indigenous Ammatoa community alone. So that PT Lonsum who is not a member of the Ammatoa Kajang customary community does not need to comply with the Kajang ri installment and unilaterally carries out forest destruction including customary Ammatoa Kajang forest and a place where the Ammatoa Kajang customary community lives as a rubber processing factory. While in the village of Balong, Ujung Loe subdistrict, which is an indigenous area of ammatoa kajang, has been taken over by PT Lonsum to become a rubber plantation. This conflict also provided a movement for the indigenous Ammatoa community together with the Indigenous Peoples Alliance of the Archipelago (AMAN) and several NGOs concerned with the environment and indigenous peoples to fight for their forest and customary land rights based on local wisdom contained in the Kajang ri Pasang.

\section{Data on the struggle for communal land of Ammatoa Kajang by PT Lonsum}

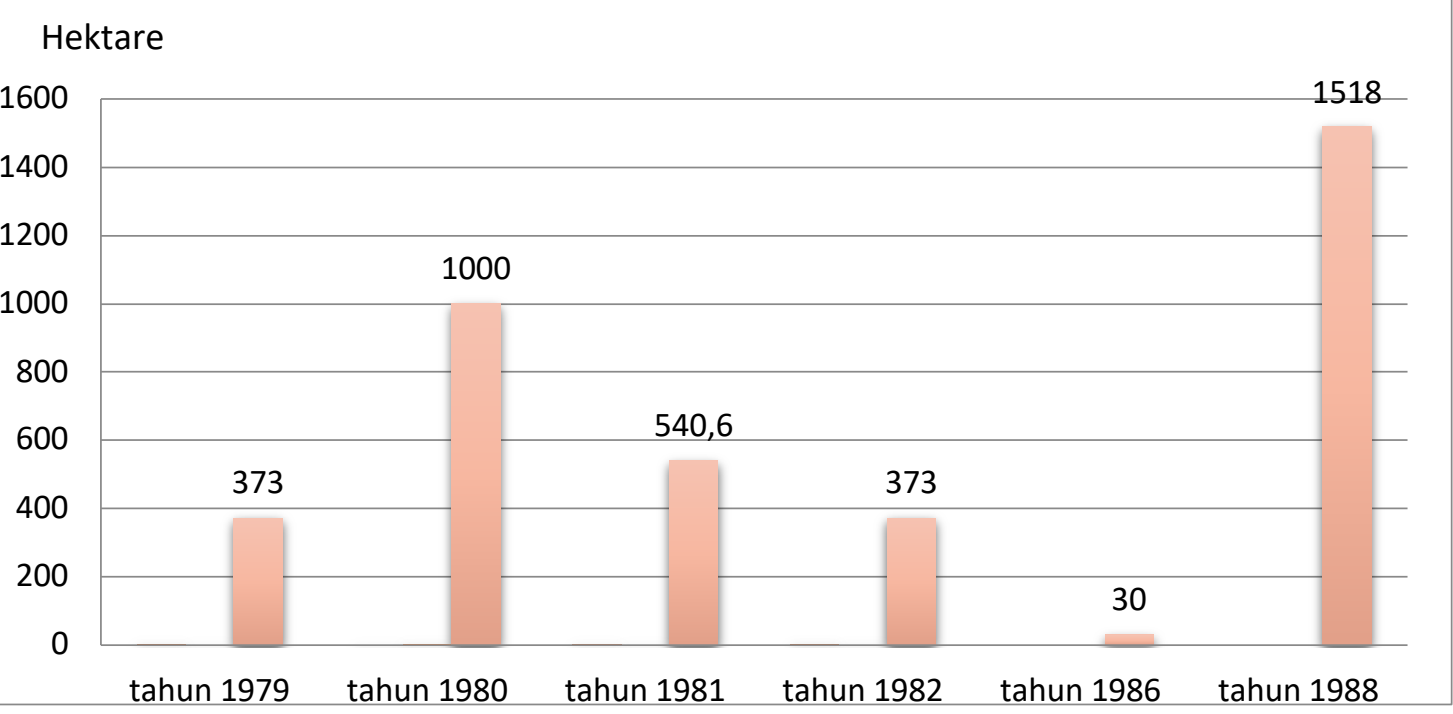

Resourch: Indigenous Peoples Alliance of the Archipelago (AMAN)

The graph shows that the struggle of ulayat land of the Ammatoa Kajang customary community by PT Lonsum was carried out not only once, but there have been five times the conflict over customary land between the indigenous people of Ammatoa Kajang and PT Lonsum. The contested customary land consists of indigenous peoples' settlements, forests, paddy fields and plantations which are the source of livelihood for indigenous peoples and some are communal land. In fact, in 1979 there was a unilateral eviction in the village of Balong which was responded to by the ammatoa kajang community in the form of protests and demonstrations, so the local government of Bulukuma district facilitated a meeting between PT Lonsum and the local community which resulted in three agreements: 
1. PT. Lonsum will not expand its plantation area, before the decision from the district court of Bulukumba district comes out.

2. PT. Lonsum together with the local government of Bulukumba Regency will compensate the eviction carried out by PT. Lonsum.

3. The family of the local community will be made as company employees.

This agreement did not last long, because in 1980 before the decision of the Bulukumba district court was issued, PT Lonsum re-expanded its plantation area unilaterally which included the customary land of ammatoa kajang and this unilateral expansion lasted until 1988.

If this unilateral takeover of land continues, it is not impossible that the indigenous people of Ammatoa will lose their customary territories, including their rights, recognition and existence as indigenous peoples. Another impact is that the community outside the Ammatoa Kajang customary community will be worried, because this eviction continues to spread and it is not impossible that the area of the community outside the indigenous community will be seized as well. This gives a big question about the effectiveness of the role of the State - the Bulukumba district government-- in protecting people's rights and prospering their communities, including indigenous peoples without exception.

The role of the State or the role of the local government of Bulukumba district in dealing with conflicts over the customary land and forest of the Ammatoa Kajang community still has not shown a positive effect on the Kajang community. This is because the state the Bulukumba district government - does not carry out deregulation. So far the coordination mechanism between the private sector / market to the community is only regulated by the private sector or the community itself, so that the role of the government becomes less effective. Deregulation is needed not only to regulate private / market mechanisms but also to give rights to the community to determine the level of their welfare.

In the conflict between the community of Ammatoa Kajang and PT Lonsum, the position of the government tended to allow the activities carried out by PT Lonsum. The research findings indicate that there is a factor that PT Lonsum is one of the biggest PAD contributors in Bulukumba district so that in determining the policies and decisions that will be taken, the regional government will be more careful and weak to intervene in PT Lonsum . PT Lonsum's bargaining position is very beneficial for the Bulukumba district government compared to the position of the Kajang's ammatoa indigenous people. This was strongly opposed by Boyer, the State must really function effectively in controlling the market mechanism. Including market or private intervention carried out by PT. Lonsum during the conflict with the Kajang Ammatoa indigenous people. The strong intervention of PT. Lonsum and its bargaining position in the local government of Bulukumba district must be stabilized immediately. If left unchecked, the role of the State will be very minimal and the welfare of the community will be threatened. Agreeing with Robert Boyer's argument, Richard Nixon argues that markets or the private sector must be tamed by laws, regulations, joint agreements, including a built in stabilizer in the Tax system. In this way the government will easily control the 
market mechanism, so that the role of the State is to govern and not the market or private sector that governs the State.

The research findings show that in the conflict between the Ammatoa Kajang community and PT Lonsum, the government's position tends to allow the activities carried out by PT Lonsum. This can be identified due to the fact that conflict occurred between PT. Lonsum and the Kajang customary community really need the role of the State, which in this case is the Regional Government of Bulukumba Regency. But before the Bulukumba district government needed to carry out their role properly. The essence of the role of the State which was intended by Robert Boyer was Deregulation. The first deregulation needs to be applied to the private mechanism. Bulukumba district government needs to establish laws or local regulations that regulate market or private mechanisms such as PT. Lonsum, this is to limit excessive market or private intervention. The second deregulation that must be done by the State is to make laws or special regional regulations for the Kajang Ammatoa indigenous people. this is intended to provide legal and legal protection to the Kajang Ammatoa indigenous people, not only their communities but also their environment, culture, cultural heritage and local wisdom.

In the discussion of the second deregulation the researcher argued, namely regarding the rights of indigenous peoples. The discourse on indigenous peoples is very beginning to be intensified, up to the international level. Advocacy efforts for indigenous people are still relatively weak. Indigenous peoples live with a burden of discrimination which has a long history, but also becomes alienated from access to their own land with all its natural wealth. Politically indigenous peoples do not have a strong bargaining position, economically they have no guarantee of survival. Especially the factors of modernization and globalization that require every human being to be able to follow the changing times that are not in accordance with their traditional values and living systems. Not surprisingly, in the next few years our children and grandchildren may no longer know what is called indigenous people.

Conflict over the customary forest of the Kajang customary community with PT. Lonsum has encouraged the Kajang Ammatoa indigenous people to make efforts to obtain recognition and protection of their rights, including rights to land and natural resources. Recognition of the existence of customary law communities was stated in the Basic Agrarian Law (UU-PA) of 1960. However at the same time, the enactment of other Laws, namely Law No. 5 of 1967 concerning the basic provisions of forestry, which was then followed by implementing regulations, namely government regulation No. 21 of 1970 concerning Forest Concession Rights (HPH). (Hijjang, 2005)

These government regulations, among others, in Article 6 paragraph 1 determine that the rights of customary law communities and their members to extract forest products, their implementation need to be regulated, so as not to interfere with the implementation of forest exploitation. And in Article 6 clause 3 it is continued that in the forest area being worked in the context of forest exploitation, the implementation of the people's right to collect forest products is frozen. Some government regulations that appear to be unequivocal in determining the position of indigenous peoples are legally a weakness to maintain the existence of indigenous peoples, including the Kajang Ammatoa 
indigenous people. In a conflict involving the Kajang Ammatoa indigenous community and PT. Lonsum really needs the role of the State - in this case the local government of Bulukumba district - to resolve the conflict over the customary forest.

The customary forest conflict between the Kajang Ammatoa indigenous people and PT. Lonsum brought a big boost to the government of the Bulukumba district to provide legal protection legally to the Kajang Ammatoa indigenous people and all of their elements. This was confirmed by the drafting of a Regional Regulation Draft concerning the Inauguration of the Protection of Recognition of the Ammatoa Kajang Customary Law Community. The plan to make this Perda has been socialized since 2008. The making of this Regional Regulation is based on conditions that are not conducive for the Kajang Ammatoa indigenous people especially since the conflict over the customary forest with PT. Lonsum takes place.

This progress became a bright spot for the Kajang Ammatoa indigenous people to be able to get legal recognition and protection from the government of the Bulukumba region. In the draft regional regulation not only discusses the handling of conflicts concerned with the Kajang Ammatoa indigenous people, it also concerns all the patterns and values of life of the Kajang Ammatoa indigenous people based on the Kajang ri. The values in the Kajang Pasang ri were adopted in the draft regional regulations as a source of value that regulates the lives of the Kajang Ammatoa indigenous people protected by law.

The process of drafting this regional regulation takes quite a long time and involves various parties in it besides the Kajang Ammatoa indigenous people, including Community Institutions such as the Indigenous Peoples Alliance of the Archipelago, Walhi, Balang Institute. In addition, one of the members of the Bulukumba district DPRD who is also the Kajang Ammatoa indigenous community , Kahar Muslim helped oversee the process of establishing a draft local regulation for the Kajang Ammatoa indigenous people.

The beginning of the process of drafting this regional regulation began with the issuance of the Decree of the Regent of Bulukumba No.760/VII/2013 concerning the Establishment of a Team for Formulating Draft Regional Regulations related to the Recognition of Customary Law Communities in Bulukumba Regency. This Compilation Team involved the Ammatoa Kajang Indigenous Community, the Bulukumba District Government in this case the Department of Reliance as the responsible SKPD, the Archipelago Indigenous Peoples Alliance (AMAN) South Sulawesi, the Balang NGO and the AgFor Sulawesi Governance Team from CIFOR. The drafting team that has been drafted contributes to a basic study of local conditions, namely the analysis of stakeholders (stakeholder analysis), formal and informal institutional arrangements, cultural and customary rules, traditional land classification of the Ammatoa Kajang customary community, forestry policies and relations between groups. This is done as an effort to formulate regulations in a participatory manner.

At the beginning of 2015 the drafting team had completed the academic paper and draft regional regulations concerning the Inauguration, Recognition and Protection of the Ammatoa Kajang Customary Law Society (P3MH). The next stage is the legislative 
process in the DPRD. The DPRD formed a Special Committee (PANSUS) to process the draft regional regulations concerning the Ammatoa Kajang indigenous people. The special committee formed by ten people, chaired by a Legislative Member of the Bulukumba Regency DPRD from the Kajang electoral district, Udin Hamzah who came from the PPP faction. In addition there was a legislative member who was joined as one of the members of the Kajang Customary Community Committee Special Committee that came from the Kajang electoral district, precisely from Tana Towa village namely Kahar Muslim from the Golkar faction.

These two legislative members from the Kajang electoral district have become a force for the Ammatoa Kajang indigenous people in their efforts to fight for their customary rights. Udin Hamzah is a former head of the village of Male'leng which is included in the Ammatoa Kajang region, while Kahar Muslim is the former head of the village of Tana Towa, the village which is the central location of the Ammatoa Kajang customary area. These two sons from the Kajang region gave a positive boost in the process of ratifying the P3MHA Regional Regulation Ammatoa Kajang, because as a community originating from Ammatoa Kajang, they will fight for and defend the rights that the Ammatoa Kajang indigenous people have.

Both the drafting team and the Special Committee have the same argument in forming the Ammatoa Kajang Customary Regulation Draft Regional Regulation, namely fighting for customary rights related to the management of nature, especially the Forest. However, in the formulation of this regulation there are dynamics and debates that are quite time-consuming. The first debate regarding the draft title of the Perda. The drafting team, especially the NGOs, argued that the draft Perda must open up space to find other Indigenous Peoples in Bulukumba District in addition to the Ammatoa Kajang Indigenous People. The reason for this argument is because so far the local government has not conducted research on the existence of indigenous peoples in Bulukukmba District, therefore research needs to be done to find indigenous communities other than Ammatoa Kajang. However, the Regional Government of Bulukumba continued to establish that this draft Perda was sufficient for the inauguration of the Kajang Ammatoa indigenous people.

Second debate about indigenous territories. Initially the Regional Government argued that the recognition of indigenous territories was only for areas in the Ammatoa region (Ilalang Embaya). However, after conducting a basic study of local conditions and the classification of traditional land in the Kajang community, finally the Compilation Team and the Special Committee could agree. Third debate about the obligations of regional governments. This is very much related to the State's obligations in the concept of train obligation (respect, protection and fulfillment) in human rights instruments. After going through debates and formulation of regional regulations, finally on November 17, 2015, the Chairman of the Bulukumba DPRD, Andi Hamzah Pangki, ratified the provisions of the Regional Regulations for the Inauguration, Recognition and Protection of the Ammatoa Kajang Customary Community written in Regional Regulation No.9 of 2015.

Regional Regulation No. 9 of 2015 consists of Thirteen Chapters with 28 Articles. This regulation discusses the Inauguration, recognition of rights and protection of the rights of the Ammatoa Kajang customary law community. This regulation also discusses the 
duties and authorities of the Regional Government towards the Ammatoa Kajang Customary Community. Ratification of Regional Regulation No. 9 of 2015 is one of the steps of deregulation carried out by the Regional Government of Bulukumba in carrying out its functions to ensure the welfare of all its people without exception. The contents of this Regional Regulation are very much based on the values of Pasang ri Kajang, including in matters of land and forest management.

In Perda No. 9 of 2015 describes the meaning of Inauguration, Recognition of Rights and Protection of Rights which is the title of P3MHA Ammatoa Kajang Regional Regulation in Chapter I, article (legal) 1 concerning General Provisions of clauses 9, 10 and 11 as follows:

(9) Inauguration is a joint determination or ratification by the regional government and DPRD on the existence of MHA Ammatoa Kajang.

(10) Recognition of MHA rights is a written statement on the existence of MHA Ammatoa Kajang and their rights granted by the regional government.

(11) Protection of MHA rights is a form of service provided by the regional government to the MHA Ammatoa Kajang in order to guarantee their rights are fulfilled, so that they can grow and develop as a community group, participate in accordance with their human dignity and protection and discrimination and violence. (Hijjang, 2005)

Pasang ri Kajang was adopted into Regulation in the Ammatoa Kajang Law Society. This regulation becomes a legal reference that protects the rights and authority of the Kajang Ammatoa indigenous people. Not only land and forest problems, but also includes the form and position of indigenous peoples, customary law community institutions, customary territories, arrangement of territories, duties and authority of the Ammatoa Kajang customary law community, indigenous peoples' rights and authority to handle disputes.

As stated in Chapter VII concerning the System of Mastery and Land Use Article 11 clause (1) which reads: The system of control and use of land in the MHA area of Ammatoa Kajang is determined based on Tide. And clause (2) which reads: Post as referred to in paragraph (1) becomes the cultural property of MHA Ammatoa Kajang. Next the author describes the contents of the articles in Chapter VII. Article 12 reads as follows:

(1) Mastery and use of land in the MHA area of Ammatoa Kajang consists of shared land and private land.

(2) The common land as referred to in paragraph (1) based on land use includes:
a. Customary forest (Borong Lompoa);
b. Tanah kalompoang / gallarang ;
c. Customary land; and
d. Land is crazy

(3) Private land as referred to in paragraph (1) based on land use includes residential land, yards, gardens and rice fields. 
(4) Borong lompoa as referred to in paragraph (2) letter a as illustrated in the map in appendix III which is an integral part of this regional regulation. (Hijjang, 2005)

Whereas in Article 13 there are 4 verses which discuss more specifically about the Ammatoa Kajang customary forest. The sound of the article is as follows:

(1) Customary forests as referred to in article 12 paragraph (2) letter a are jointly owned land in the MHA area of Ammatoa Kajang which the ownership and utilization status cannot be changed.

(2) Customary forests consist of Borong Lompoa / large forest and Palleko'na Boronga ' / small forest.

(3) Borong Lompoa covers all natural resources and cultural resources in which there are plants, wild animals, lakes, springs, and saukang.

(5) Boronga 'Palleko'na is located in ten locations, the Karenglohe Forest, Kalimbuara Forest, Barombong Forest, Pudondo Forest', Buki 'Madu Forest, Buki'a Forest, Sangkala Forest Lombok, Pokkolo Forest, Tamaddohong Forest and Bongki Forest.

In this regulation also explains the Rights of the Ammatoa Kajang Customary Law Community described in Chapter IX which consists of six parts. Two parts include regulating communal land and customary forests. The first part discusses the Rights to Land, Territories and natural resources consisting of two articles. Article 15 consists of 3 clauses as follows:

(1) MHA Ammatoa Kajang has the right to lands, territories and natural resources that they have or occupy for generations and / or obtained through other mechanisms.

(2) Natural resources as referred to in clause (1) include all things both surface and contained in the soil.

(3) The rights to land, territory and natural resources as referred to in clause (1) include the right to own, use, develop and control on the basis of hereditary ownership and / or other means.

Article 16 then reads as follows:

(1) Land rights can be communal / collective and / or individual in nature in accordance with local customary law.

(2) Rights to tanag which are communal / collective cannot be transferred to other parties.

(3) Rights to individually owned land can only be transferred in accordance with the requirements and processes determined by customary law.

(4) Communal / collective land use and individual land within customary territories by other parties can only be done through a mechanism of joint decision making based on customary law. (Hijjang, 2005)

Other sections concerning environmental issues described in Chapter IX of Regional Regulation No. 9 of 2015 is the fourth part that discusses the Right to the Environment. The first is outlined in article 19 which reads:

(1) MHA Ammatoa Kajang has the right to a healthy environment. 
(2) In order to fulfill the healthy environment requirements as referred to in clause (1) MHA Ammatoa Kajang has the right to obtain environmental education, access to information, and broad participation in environmental management and protection.

Furthermore, in Article 20 there are two verses which discuss further about the environment, which reads as follows:

(1) MHA Ammatoa Kajang has the right to restoration and protection of the environment which has been damaged in the customary territory.

(2) The recovery of the damaged environment in the adat area is carried out by taking into account the proposed environmental recovery activities proposed by the affected MHA Ammatoa Kajang including the consideration of environmental recovery procedures based on their local wisdom.

Some of the articles outlined above are elaborated in the form of positive law on the existence of Pasang ri Kajang as a local wisdom. Ratification of Regional Regulation No. 9 of 2015 concerning Inauguration, Recognition of Rights and Protection of Rights Ammatoa Kajang customary community is proof that the State has carried out deregulation which is one of the solutions to maintain the survival of indigenous peoples and even their nature and environment. The state in this case the local government of Bulukumba district deregulated the rights of the Ammatoa Kajang indigenous people. These rights as previously described cover various aspects of social life, government, beliefs, culture, identity and environment that refer to the Kajang ri ri. One of the things regulated in making this deregulation is the management of natural resources, including land and forests. The values in the Pasang Ri Kajang governing forest problems are very clear. Not only for the forest, but also regulates the life of nature and all its contents. If observed, the deregulation carried out by the government did not have a direct impact on the environment, because Regional Regulation No. 9 of 2015 which was ratified addressed to the Ammatoa Kajang indigenous people, in this case state deregulation is oriented to human interests and needs.

\section{Conclusion}

Pasang ri Kajang has an environmental ethic that very well regulates the relationships and actions that a human being has to do with nature, especially the forest. Forests for the Ammatoa Kajang indigenous people are a source of life and kindness. So if this forest is damaged or not maintained, then the entire balance of ecosystems within the Ammatoa Kajang indigenous community will be damaged.

Conflict over customary forests that involve the Kajang Ammatoa indigenous community with PT. Lonsum is the beginning of the movement of the Ammatoa Kajang indigenous people in fighting for their customary rights. The eviction of ulayat land and customary forests was carried out unilaterally by PT. Lonsum drew protests from the indigenous people of Ammatoa Kajang and NGO Parties observing the Environment. This eviction is a threat to the destruction of nature, life and even the existence of the Kajang indigenous people. the resistance of indigenous peoples is very weak, given the 
intervention of PT. Lonsum in the local government is very influential. Moreover, the recognition of the Ammatoa Kajang customary forest is weaker in the State perspective. a concern about the threat to their existence and customary rights. As a form of resistance to fight for their customary rights, the Ammatoa Kajang community along with environmental and indigenous peoples' observers submitted a regional regulation on the Ammatoa Kajang indigenous people. The purpose of this Draft Regional Regulation is to recognize and protect the legal and customary rights of the Ammatoa Kajang indigenous people. And in November 2015, the Regional Regulation No. 9 of 2015 was passed on the Inauguration, Recognition and Protection of the Rights of Indigenous Peoples of Ammatoa Kajang.

In Perda No. 9 of 2015 contains Recognition of the Kajang Ammatoa indigenous people, legal protection, inauguration as a legal customary community, customary law community institutions, indigenous territories of the Kajang Ammatoa community, Land Control and Utilization System, duties and authority of the Kajang Ammatoa customary community, the rights and authority of indigenous peoples, the duties and authority of the regional government and the handling of disputes involving the Kajang Ammatoa indigenous people. With the existence of this regulation deregulation, it is expected that in the future the recognition of the outside community towards the Ammatoa Kajang customary community is more attention and able to strengthen the existence of the Ammatoa Kajang customary community in the eyes of the Law.

\section{Conflicts of Interest:}

The authors declare that there is no conflict of interest.

Acknowledgement:

Thanks to the Bulukumba Regency government and the Kajang Indigenous Community for providing the opportunity to conduct research in the Kajang customary area.

\section{References}

Boyer, R. (2005). tate and Market: A New Engagement for the twenty-first century, in Robert Boyer $\mathcal{E}$ Daniel Drache, State against Markets: The Limits of Globalization. New York: Routledge Press.

Constitution of the Republic of Indonesia. (t.thn.). The 1945 Constitution of the Republic of Indonesia. Indonesia.

Hijjang, P. (2005). Tide and Ammatoa Leadership: Re-understand the Traditional Leadership System of Indigenous Peoples in Forest Resource Management in Kajang, South Sulawesi. Journal of Indonesian Technology, 29(3), 263.

Suci, U. F. (2016). Ecocentrism of the Ammatoa Kajang Indigenous Community in Maintaining Customary Forest in Bulukumba Regency.

James Connelly \& Graham Smith. (2003). Politics and the Environment: from theory to practice, second edition. Rout ledge press. New York.

Edy, Rafael B. (2006). Rights of Indigenous Peoples in the Context of Natural Resource Management. ELSAM, Jakarta.

Erman Syarif, Ach Fatchan, Sumarmi, I Komang Astina. (2016) Tradition of "Pasang RiKajang" in the Forests Managing in System Mores of "Ammatoa" at District Bulukumba South Sulawesi, Indonesia. Mediterranean Journal of Social Sciences. Vol. 7 Numb. 6. P 327. 
Mahmud. (2020). Settlement of Land Dispute Rights Ulayat Peoples Kajang with PT. PP London Sumatera Indonesia in Bulukumba District. Journal Indonesia Law \& Policy Review. P. 74

H K Surtikanti, A Syulasmi, N. Ramdhani (2017). Traditional Knowledge of Local Wisdom of Ammatoa Kajang Tribe (South Sulawesi) about Environmental Conservation. Journal of Physics Conf Series 895(012122). P. 3.

Sampean S., Sofyan Sjaf (2020). The reconstruction of Ethnodevelopment in Indonesia: A New Paradigm of Village Development in the Ammatoa Kajang Indigenous Community, Bulukumba Regency, South Sulawesi. MASYARAKAT: Jurnal Sosiologi, Vol. 25 No. 2, P. 171.

Bulukumba Regency DPRD. Regional Regulation of Bulukumba Regency Number 9 of 2015 concerning Inauguration, Recognition of Rights, and Protection of the Rights of Indigenous Law Community Ammatoa Kajang, Chapter I, Article 1 paragraph (9), (10), (11).

Bulukumba Regency DPRD. Regional Regulation of Bulukumba Regency Number 9 of 2015 concerning Inauguration, Recognition of Rights, and Protection of the Rights of Indigenous Law Community Ammatoa Kajang, Chapter VII, Article 12 paragraph (1), (2), (3), (4).

Bulukumba Regency DPRD. Regional Regulation of Bulukumba Regency Number 9 of 2015 concerning Inauguration, Recognition of Rights, and Protection of the Rights of Indigenous Law Community Ammatoa Kajang,Chapter IX, Article 15 paragraph (1), (2), (3). 